Chirurgia (2017) 112: 124-129

No. 2, March - April

Copyright $\odot$ Celsius

\title{
Laparoscopic Donor Nephrectomy of Dual Renal Artery Kidneys: Single Center Experience*
}

\author{
Ibrahim Al-Oraifi', Mansour Tawfeeq ${ }^{1}$, Hamad Al-Hellow', Mohammed S Al-Qahtani', Meteb M Al-Bugami', \\ Abdulwahab Al-Shahrani', Gelu Osian ${ }^{1}$ \\ 'Multi-Organ Transplant Center, King Fahad Specialist Hospital, Dammam, Saudi Arabia \\ ${ }^{2}$ Department of Internal Medicine, College of Medicine, University of Dammam, Dammam, Saudi Arabia
}

Corresponding author:

Gelu Osian, MD, PhD

MOTC, King Fahad Specialist

Hospital-Dammam

P. 0. Box 15215, Dammam 31444

Saudi Arabia

E-mail: gelu.osian@kfsh.med.sa

*Awarded as a Poster of Distinction at the ATC 2015 Meeting, Philadelphia, USA

\section{Abbreviations:}

CIT: cold ischemia time;

DGF: delayed graft function;

DRA: dual renal artery;

LDN: laparoscopic donor nephrectomy;

LKD: living kidney donor;

LOS: length of stay;

MRA: multiple renal artery;

SRA: single renal artery;

TOT: total operative time;

WIT: warm ischemia time

Received: 20.03.2017

Accepted: 10.04.2017

\section{Rezumat}

Nefrectomia laparoscopică la donatorii cu artere renale multiple: experiența unui singur centru

Introducere: Rinichii cu artere multiple reprezintã o provocare deosebitã pentru chirurg, atât în timpul nefrectomiei la donator cât şi al transplantului renal.

Scopuri: Scopurile acestui studiu sunt evaluarea rezultatelor atât a donatorilor cât şi a recipienților rinichilor cu artere multiple procurați pe cale laparoscopicã.

Pacienți şi Metodã: Am analizat retrospectiv datele medicale a tuturor recipienților şi a donatorilor vii care au donat rinichi pe cale laparoscopicã între aprilie 2009 şi decembrie 2014. Detaliile intraoperatorii şi evoluția imediatã au fost comparate între donatorii şi recipienții de rinichi cu artere multiple şi donatorii şi recipienții de rinichi cu arterã renalã unicã.

Rezultate: Dintr-un total de 250 donatori la care s-a practicat nefrectomia laparoscopicã $43(17,2 \%)$ au avut artere renale multiple. Timpul operator mediu a fost semnificativ statistic mai lung în grupul cu artere multiple (168,1 min vs $135,3 \mathrm{~min} ; \mathrm{p}=0,001)$, cu toate acestea durata ischemiei calde, respectiv rece, au fost similare în cele douã grupuri. $\mathrm{Nu}$ au fost consemnate complicații la donatorii din ambele grupuri, nici conversii la nefrectomia pe cale deschisã. Durata spitalizãrii postoperatorii a fost similarã pentru cele douã grupuri. Deasemenea nu a existat nici o diferențã semnificativã statistic între rata funcționãrii imediate a grefelor renale din ambele grupuri.

Concluzii: Nefrectomia laparoscopicã la donatorii cu artere multiple este o procedurã sigurã şi nu are un impact semnificativ asupra evoluției ulterioare a donatorului sau a funcționãrii grefei renale. 
Cuvinte cheie: transplant renal, nefrectomie laparoscopicã, donator viu, artere renale multiple, funcția grefei renale

\begin{abstract}
Background: Multiple renal artery (MRA) kidneys represent a special challenge for surgeons, during both donor nephrectomy and renal transplantation.

Aims: This study aims to evaluate both donors' and recipients' outcomes of laparoscopically procured dual renal artery (DRA) kidneys.

Patients and Methods: We reviewed the medical records of all living kidney donors who underwent laparoscopic donor nephrectomy between April 2009 and December 2014, and their recipients. Operative details and immediate outcomes of both donors and recipients of DRA kidneys were compared to those of donors and recipients of single renal artery (SRA) kidneys.

Results: From a total of 250 laparoscopic donor nephrectomies, 43 (17.2\%) were on kidneys having DRAs. The mean operative time was statistically higher in the group with DRA (168.1 mins vs 135.3 mins, $\mathrm{p}=0.001$ ), however, mean warm and cold ischemia times were the same. There were no complications reported among donors in neither groups, nor conversion to open nephrectomy. Lengths of hospital stay of the donors were similar in both groups. There was no statistically significant difference in immediate allograft function among the two groups.

Conclusions: Laparoscopic procurement of kidneys with dual renal arteries is safe, reliable, and has no significant impact on the neither donor's outcome, nor allograft function.
\end{abstract}

Key words: kidney transplant, laparoscopic donor nephrectomy, multiple renal arteries, allograft function

\section{Introduction}

Renal transplantation is the only cure for patients with end-stage renal disease. However, this treatment modality is not readily available for all patients. It requires a specialized center of excellence, fellowship trained surgeons and an extremely intricate network of transplantation and organ procurement organization staff. Due to the ongoing supply-demand mismatch between the available organs and patients who desperately need them, most of the transplant centers have adopted laparoscopic donor nephrectomy $(\mathrm{LDN})$ in order to expand the living kidney donor (LKD) pool. By minimizing morbidity, lowering costs, and expediting recovery of living kidney donor, LDN might increase the number of kidneys available for transplantation (1). Moreover, transplanting renal allografts procured laparoscopically has been shown to provide short and long term out- comes comparable to outcomes of open donor nephrectomy (2).

The first LDN took place in 1995 (3), with encouraging results from both the donor and recipient perspectives. Initially, $\mathrm{LDN}$ was limited to procure kidneys with single renal artery (SRA), as multiple renal artery (MRA) kidneys were considered inappropriate for laparoscopic procurement. Since the presence of MRAs is considered the most common renal anatomic variation, with prevalence of up to $30 \%$ (4), considerable number of potential LKDs would be precluded from this minimally invasive surgery. However, with increasing experience and improving technique, LDN has been extended to donors with MRAs. Despite that, some transplant surgeons might still rule out the option of LDN upon encountering potential LKDs with MRA kidneys because the procedure is still technically challenging, with the ongoing concerns regarding prolonged 
operative times, ischemia time, and increased risk of complications $(5,6)$.

The aim of this study was to compare laparoscopically procured MRAs kidneys with SRA kidneys focusing on surgical procedure and immediate allograft outcome.

\section{Materials and Methods}

The study was approved by the hospital's Institutional Review Board. All adults (age 18 years and above) LKDs who underwent LDN between April 2009 and December 2014 were included. All LKDs have gone through an extensive medical, surgical and psychosocial evaluation. Part of that evaluation was delineating renal anatomy using multidetector computed tomographic angiography. Due to lack of experience at the beginning, during this interval per center protocol all potential donors having three or more renal arteries were excluded from donation, only donors with single or dual renal artery were accepted. Medical records of the donors and their recipients were reviewed. Data collected included the number of arteries per kidney, LDN total operative time (TOT), warm ischemia time (WIT), and cold ischemia time (CIT). Donors' length of stay (LOS) and presence of post-operative complications were collected. Allograft function was assessed by presence of delayed graft function (DGF), which was defined as requiring dialysis during the first week of transplantation, and serum creatinine levels at day-1, -5 , and -30 . Presence of complications on day-1 Doppler ultrasound, which is a routine practice in our center was reported. Outcomes of DRA kidneys were compared to outcomes of SRA kidneys.

LDN procedure was performed using both standard laparoscopic technique, with three trocars and Pfannenstiel incision for extraction, and hand assisted laparoscopy. Once out, the kidneys were flushed with cold University of Wisconsin [Viaspan (Bristol-Myers Squibb)] or histidine-tryptophan-ketoglutarate [HTK; Custodiol (Essential Pharmaceuticals)] preservation solution. A routine post procurement bench reconstruction was performed for MRA kidneys. The arteries were joined together in a double-barrel fashion in most of the cases. In situation when arteries were too far apart in order to avoid tension we decided for separate arterial anastomosis.

The recipients underwent the transplantation procedure using the standard extraperitoneal approach with end-to-side anastomosis of donor renal vessels to recipient external iliac vessels. All recipients received subcutaneous unfractionated heparin as venous thromboembolism prophylaxis. Recipients of DRA kidneys received low dose aspirin starting postoperative day 1 . Ureteral stents were routinely used, and attached to the tip of the Foley catheter. The stent was removed with the Foley catheter on postoperative day 5 .

Statistical analysis was carried out using Stata version 14.1 (StataCorp, College Station, TX, USA). Data were expressed as mean \pm standard deviation for numerical variables and as frequency (percentage) for categorical variables. In order to compare the two groups, ttest or chi-square test were used as appropriate. For all analyses, a $p$ value $\leq 0.05$ was considered statistically significant.

\section{Results}

Two hundred and fifty LDNs were performed during the study period; $43(17.2 \%)$ donors had DRA kidneys and 207 (82.8\%) donors had SRA kidneys. Baseline characteristics of donors and recipients (Table 1) for both DRA and SRA kidney groups were the same.

Operative details are shown in Table 2. TOT was longer when dealing with DRA kidneys (168.1 \pm 6.9 mins vs $135.3 \pm 6.5$ mins, $p=0.001$ ). However, WIT during LDN procedures was the same among both groups averaging at 4.6 minutes and 4.0 minutes for both DRA kidneys and SRA kidneys, respectively. Within the DRA group, there were no differences between the hand assisted and standard laparoscopic nephrectomies with regards to TOT (165.9 mins vs 170.3 mins, $\mathrm{p}=0.31$ ) and WIT (4.3 mins vs 4.9 mins, $p=0.33$ ). Vascular anastomosis time was slightly higher in kidneys from DRA but there was no statistical significance (42.3 mins vs 30.6 mins, $\mathrm{p}=0.93$ ). 
Table 1. Baseline characteristics of the study groups

\begin{tabular}{|c|c|c|c|c|}
\hline \multicolumn{2}{|l|}{ Characteristic } & \multirow{2}{*}{$\begin{array}{c}\text { DRA Kidney }(\mathrm{N}=43) \\
30 \pm 9\end{array}$} & \multirow{2}{*}{$\begin{array}{c}\text { SRA kidney }(\mathrm{N}=207) \\
35 \pm 8\end{array}$} & \multirow{2}{*}{$\begin{array}{c}P \text { value } \\
0.21\end{array}$} \\
\hline Donor: & Age -mean $\pm S D$, years & & & \\
\hline & Female Gender - N (\%) & $8(19)$ & $74(36)$ & 0.1 \\
\hline \multirow[t]{2}{*}{ Recipient: } & Age - mean $\pm S D$, years & $38 \pm 16$ & $43 \pm 13$ & 0.32 \\
\hline & Female Gender - N (\%) & $15(35)$ & $98(48)$ & 0.19 \\
\hline ESRD Cause: & Intrinsic Renal - N (\%) & $38(88)$ & $194(94)$ & 0.56 \\
\hline & Urological - N (\%) & $5(12)$ & $13(6)$ & 0.38 \\
\hline Single Renal & Vein - N (\%) & $31(72)$ & $178(86)$ & 0.97 \\
\hline
\end{tabular}

Abbreviations: DRA: dual renal artery; SRA: single renal artery

Table 2. Operative time

\begin{tabular}{lccc}
\hline Mean time & $\begin{array}{c}\text { DRA Kidney } \\
\text { Mean } \pm \text { SD, Min }\end{array}$ & $\begin{array}{c}\text { SRA kidney } \\
\text { Mean } \pm \text { SD, Min }\end{array}$ & P value \\
\hline TOT & $168.1 \pm 6.9$ & $135.3 \pm 6.5$ & 0.001 \\
\hline Donor WIT & $4.6 \pm 0.6$ & $4.0 \pm 0.7$ & 0.71 \\
\hline Vascular anastomosis time & $42.3 \pm 8.4$ & $30.6 \pm 4.9$ & 0.93 \\
\hline CIT & $161.3 \pm 54.9$ & $150.1 \pm 41.1$ & 0.87 \\
\hline Abbra
\end{tabular}

Abbreviations: CIT: cold ischemia time; DRA: dual renal artery; SRA: single renal artery; TOT: total operative time; WIT: warm ischemia time

There was no single case converted from laparoscopic approach to open nephrectomy in both groups. None of the donors required reoperation, and there was no post operative bleeding in both groups. The average length of stay (LOS) was similar in both groups, averaging the $4.7 \pm 1.0$ days for DRA kidney group, and $4.9 \pm 1.0$ days for SRA kidney group $(\mathrm{P}=0.32)$.

Recipients of both, DRA and SRA kidneys had no major complications. There was no single case of DGF, no renal artery or vein thrombosis reported on post operative day-1 Doppler ultrasound, and no urological compli- cations. Postoperatively, serum creatinine dropped to comparable levels in both groups, at dat $-1,-5$, and -30 (Table 3).

\section{Discussion}

During the last twenty years; laparoscopy has become the procedure of choice for living donor nephrectomy, replacing the open technique in most of the centers worldwide. In this study, we present our experience with LDN and to compare the renal allograft outcome between cases with single versus dual arteries.

Laparoscopic surgery has many advantages

Table 3. Serum creatinine levels

\begin{tabular}{lccc}
\hline Serum creatinine level & $\begin{array}{c}\text { DRA Kidney } \\
\text { Mean } \pm \text { SD, umol/L }\end{array}$ & $\begin{array}{c}\text { SRA kidney } \\
\text { Mean } \pm \text { SD, umol/L }\end{array}$ & $\boldsymbol{P}$ value \\
\hline Pre transplant & $830 \pm 297$ & $905 \pm 352$ & 0.17 \\
\hline Day-1 post transplant & $337 \pm 167$ & $361 \pm 174$ & 0.19 \\
\hline Day-5 post transplant & $131 \pm 129$ & $148 \pm 62$ & 0.24 \\
\hline Day-30 post transplant & $92 \pm 37$ & $83 \pm 28$ & 0.13 \\
\hline
\end{tabular}

Abbreviations: DRA: dual renal artery; SRA: single renal artery 
compared to open surgery. It is associated with a significant improvement in postoperative pain control, less trauma to the abdominal wall, better postoperative respiratory function, a reduction in hospital LOS, earlier return to normal activities, and faster convalescence with improved wound cosmesis (7). Furthermore, LDN has been shown to provide similar shortand long- term renal allograft outcomes, and donor safety compared with open donor nephrectomy (2). Utilizing laparoscopy for living kidney donor surgery has resulted in significant rise in the rate of living kidney donation (8). Our series has one of the highest rates of $\mathrm{LDN}$ for donors with MRA among the studies published in the last 10 years. $17.2 \%$ of our donors had DRA while in the literature the rate of laparoscopic LDN for MRA varies from $7 \%$ (9) to $27.4 \%$ (10).

Preoperative accurate delineation of the renal vascular anatomy is an important step, as LDN is technically challenging compared with open nephrectomy. Computed tomographic angiography has been shown to have an accuracy rate reaching up to $98 \%$, with sensitivity and specificity of $86-88 \%$ and 98 $100 \%$, respectively, on assessing renal vascular anatomy $(11,12)$. In this study, multidetector computed tomographic angiography was done for all donors and was sufficiently accurate for correctly identifying renal vessels. There were no false-positive or false-negative results. In another study, one out of thirty-one donors had a preoperative scan suggesting two renal arteries, however intraoperatively he was found to have four (13). Upon reviewing the scan postoperatively, this was due to the superimposed visual images of the adjacent renal arteries giving a reconstituted image that did not distinguish the multiplicity of the vessels.

The operative time is slightly longer in donors with DRA and this is not necessarily due to multiple arteries itself. In about $28 \%$ of the DRA cases, there were also multiple veins which made the time to dissect the arteries and veins longer. Both WIT and CIT in this study were shorter than other reports $\left(10,14^{-}\right.$ 16). This is probably influenced by having available operation rooms for the donor and recipient at the same time in most of the cases.

In terms of technical aspects there was no significant difference between hand assisted and standard laparoscopic nephrectomy for DRA, it remains to the latitude of surgeon's training and experience which one should be used. In the case of difficulty reconstructing the arteries on the back-table, there is always the option of two separate anastomoses with similar results to the double-barrel technique. Actually the progress and accumulation of experience makes MRA donors part of the routine activity, even with single incision laparoscopic surgery approach (17).

This study confirmed findings from other reports $(8,13,18)$; recipients of laparoscopically procured DRA kidneys are not at increased risk of vascular or urological complications. Saidi et al compared 31 MRA kidneys with 319 SRA kidneys and found no differences between the two groups on the rates of vascular and urological complications (9.6\% vs 9.7\%; vascular, $2.8 \%$ vs $3.2 \%$; urological) (13). In another study, Chedid et al found no significant differences in vascular complications $(2.4 \%$ vs $1.1 \%, \mathrm{p}=0.17)$ and urologic complications $(2.9 \%$ vs $3.1 \%$, $\mathrm{p}=0.47$ ) when comparing 210 MRA kidneys to 924 SRA kidneys (18). Furthermore, they have shown that multiplicity of renal arteries was not associated with increasing risk of vascular or urological complications in univariate analyses. On the other hand, some studies have reported increased risk of surgical complications, acute tubular necrosis, and acute rejection after transplanting MRA kidneys (4-6). This discrepancy might be attributed to the advances in LDN techniques, and early introduction of subcutaneous heparin and aspirin.

DGF has not been reported in this study, a finding that supports the safety of laparoscopically procured DRA kidneys. In one of the largest reports, Cooper et al showed similar rates of DGF between DRA and SRA kidneys (5.2\% and $5.3 \%$, respectively), however a higher DGF rate among recipients of $>2$ arteries (9.8\%) (8). One of the explanations for this finding, can be our short warm and cold ischemic times. Immediate renal allograft 
function, as reflected by day $-1,-5$, and -30 post transplant serum creatinine levels, were the same among the two groups. This finding echoes what has been reported in other studies $(8,19)$. Furthermore, short and long term outcomes are comparable between MRA and SRA kidneys $(13,18)$.

Limitations of this study include being retrospective, and the chance of introducing selection bias as potential LKDs with $>2$ renal arteries were precluded from donation. That was a policy from the center as the Renal Transplant Program was launched several months before introducing LDN. Another limitation is the short term follow-up. Since the vast majority of the complications of transplanting MRA kidneys, whether surgical or medical, are immediate, we elected to report the renal allograft function one-month post transplant. Lastly, using serum creatinine levels as a measure of the renal allograft function might not be entirely accurate, but this is currently what is used in daily practice.

\section{Conclusion}

In conclusion, DRA still represents a special challenge during both donor nephrectomy and renal transplantation. However, laparoscopic procurement of DRA kidneys has been proven to be safe and has no significant impact on renal allograft outcome. LDN should be the standard of care in living kidney donor transplantation regardless the number of renal arteries. Expanding laparoscopy use to these cases will increase the donor pool for living donor renal transplant.

\section{Acknowledgment}

We thank Adam S. Weltz, MD for reviewing the manuscript.

\section{Disclosure}

None of the authors have any conflicts to declare.

\section{References}

1. Shafizadeh S, McEvoy JR, Murray C, Baillie GM, Ashcraft E, Sill T, et al. Laparoscopic donor nephrectomy: Impact on an established renal transplant program. Am Surg. 2000;66(12):1132-5.

2. Nicholson ML, Kaushik M, Lewis GR, Brook NR, Bagul A, Kay MD, et al. Randomized clinical trial of laparoscopic versus open donor nephrectomy. Br J Surg. 2010;97(1):21-8. doi: 10.1002/bjs.6803.

3. Ratner LE, Ciseck LJ, Moore RG, Cigarroa FG, Kaufman HS, Kavoussi LR. Laparoscopic live donor nephrectomy. Transplantation. 1995; 60(9):1047-9.

4. Roza AM, Perloff LJ, Naji A, Grossman RA, Barker CF. Living-related donors with bilateral multiple renal arteries. A twenty-year experience. Transplantation. 1989;47(2):397-9.

5. Carter JT, Freise CE, McTaggart RA, Mahanty HD, Kang SM, Chan $\mathrm{SH}$, et al. Laparoscopic procurement of kidneys with multiple renal arteries is associated with increased ureteral complications in the recipient. Am J Transplant. 2005;5(6):1312-8.

6. Fuller TF, Deger S, Büchler A, Roigas J, Schönberger B, Schnorr D, et al. Ureteral complications in the renal transplant recipient after laparoscopic living donor nephrectomy. Eur Urol. 2006;50(3):53540; discussion 540-1. Epub 2006 Mar 29.

7. Buia A, Stockhausen F, Hanisch E. Laparoscopic surgery: A qualified systematic review. World J Methodol. 2015;5(4):238-54. doi: 10.5662/wjm.v5.i4.238. eCollection 2015.

8. Cooper M, Kramer A, Nogueira JM, Phelan M. Recipient outcomes of dual and multiple renal arteries following 1000 consecutive laparoscopic donor nephrectomies at a single institution. Clin Transplant. 2013;27(2):261-6. doi: 10.1111/ctr.12062. Epub 2013 Jan 10.

9. Kapoor A, Lambe S, Kling AL, Piercey KR, Whelan PJ. Outcomes of laparoscopic donor nephrectomy in the presence of multiple renal arteries. Urol Ann. 2011;3(2):62-5. doi: 10.4103/0974-7796.82169.

10. Hsu TH, Su LM, Ratner LE, Trock BJ, Kavoussi LR. Impact of renal artery multiplicity on outcomes of renal donors and recipients in laparoscopic donor nephrectomy. Urology. 2003;61(2):323-7.

11. Kim JK, Park SY, Kim HJ, Kim CS, Ahn HJ, Ahn TY, et al. Living donor kidneys: usefulness of multi-detector row CT for comprehensive evaluation. Radiology. 2003;229(3):869-76. Epub 2003 Oct 30.

12. Namasivayam S, Small WC, Kalra MK, Torres WE, Newell KA, Mittal PK. Multidetector-row CT angiography for preoperative evaluation of potential laparoscopic renal donors: how accurate are we? Clin Imaging. 2006;30(2):120-6.

13. Saidi R, Kawai T, Kennealey P, Tsouflas G, Elias N, Hertl M, et al Living donor kidney transplantation with multiple arteries: recent increase in modern era of laparoscopic donor nephrectomy. Arch Surg. 2009;144(5):472-5. doi: 10.1001/archsurg.2009.49.

14. Kadotani Y, Okamoto M, Akioka K, Ushigome H, Ogino S, Nobor S, et al. Management and outcome of living kidney grafts with multiple arteries. Surg Today. 2005;35(6):459-66.

15. Thomas AJ. Re: Desai MR, Ganpule AP, Gupta R, Thimmegowda M. Outcome of renal transplantation with multiple versus single renal arteries after laparoscopic live donor nephrectomy: a comparative study. Urology 2007; 69: 824-827. Urology. 2008;71(4):758-9; author reply 459. doi: 10.1016/j.urology.2007.11.153.

16. Kok NF, Dols LF, Hunink MG, Alwayn IP, Tran KT, Weimar W, et al Complex vascular anatomy in live kidney donation: imaging and consequences for clinical outcome. Transplantation. 2008;85(12): 1760-5. doi: 10.1097/TP.0b013e318172802d.

17. Barth RN, Phelan MW, Goldschen L, Munivenkatappa RB, Jacobs SC Bartlett ST, et al. Single-port donor nephrectomy provides improved patient satisfaction and equivalent outcomes. Ann Surg. 2013;257(3): 527-33. doi: 10.1097/SLA.0b013e318262ddd6.

18. Chedid M, Muthu C, Nyberg S, Lesnick T, Kremers W, Prieto M, et al. Living donor kidney transplantation using laparoscopically procured multiple renal artery kidneys and right kidneys. J Am Coll Surg. 2013 Jul;217(1):144-52; discussion 152.

19. Genc V, Karaca A, Orozakunov E, Cakmak A, Sevim Y, Ustuner E, et al. Multiple renal arteries challenge in laparoscopic donor nephrectomy: How far can we go? J Korean Surg Soc. 2011;80(4):272-7. 